seguida o Autor descorre sobre a estrutura interna do antigo SPI, seus principais problemas e sua extinção em dezembro de 1967, atribuida sobretudo à carência de recursos e às más administrações. Analisa em seguida a criação do novo organismo, a Fundação Nacional do Índio, instituida por lei de 5 de dezembro de 1967: seu regimento interno, sua administração, assim como o "estatuto do índio", que à imitação da lei de 1928, subdivide os aborígenes em quatro grupos:

1. - em estado tribal;

2. - em estado semi-tribal;

3. - em processo de integração;

4. - assimilados e adaptados (p. 34).

Conclui a obra um sumário (em portugues e inglês). Trabalho de muita utilidade para o historiador, para o antropólogo, para o legista e para o público em geral interessado em conhecer tais aspectos do problema indígena brasileiro, só lastimamos que E. Arnaud não tenha ido diretamente às fontes primárias na sua compilação sobre a legislação sobre os índios. A transcrição de um maior número de textos básicos, sobretudo para os períodos da Colônia e Império, e a indicação, por exemplo, de Relatórios Presidenciais que tratassem de assuntos referentes aos indigenas das diferentes províncias do Império, certamente que teriam feito desta obra um vademecum de valor muito mais substantivo.

\title{
LUIZ MOTT
}

TAYLOR (Ronald) (Compiled by). - A Collection of Writings from the Eighteenth to the Twentieth Century. London. G. Bell \& Sons. 1973. 2 vols.

O Professor de Língua e Literatura Alemães da Universidade de Sussex, Ronald Taylor, preparou uma esplêndida antologia do pensamento e da cultura alemães. O livro é dividido em dois volumes, o primeiro sobre filosofia, religião e arte, e o segundo sobre história e sociedade. A idéia de divisão temática valorizou a coleção, dando ao leitor a liberdade de escolher suas leituras. Somente o título, as pequenas introduções e as poucas notas são escritos em inglês; o tẹto escolhido, e sempre bem escolhido de edições reputadas, é reproduzido no original alemão. Trata-se, portanto, de uma antologia, um documentário literario, como está hoje tão em moda, que serve e serve bem a professores e estudantes da língua e da literatura alemães.

O primeiro volume contem textos essenciais de dezenove autores: Lessing, Herder, Kant, Schiller, Fichte, Schelling, Goethe, Hölderlin, Schlegel, Hoffmann, 
Hegel, Schopenhauer, Nietzsche, Dilthey, Döblin, Jaspers, Heidegger, com vinte textos, sendo Nietzsche o único com dois textos (Vom den ersten und letzten Dingen - Dos primeiros e últimos objetos; e Mahnruf an die Deutschen Grito de advertência aos alemães), ambos das Obras Completas, edição de Munique de 1922. A escolha é bem feita, vem de Lessing (1729-1781) até Heidegger (1889-), e são este (Was heisst Denken - O que significa pensar) e Dilthey (Die Kultur der Gegenwart und die Philosophie - A Cultura do Presente e a Filosofia) os únicos textos já traduzidos, o primeiro em português e o segundo em espanhol, Hegel (Ueber das Wesen der philosophischen Kritik Sobre a essência da crítica filosófica), Dilthey, Jaspers e Heidegger são os únicos com traduções espanholas e portuguesas, tendo Dilthey obras completas em espanhol.

O segundo volume vem de Herder (1774-1803) a Adorno (1903-1969) e constitui tambem uma exemplar seleção de textos fundamentais. São quinze autores e se rão erro nenhum tem tradução portuguesa, e todos cobrem, com a conhecida profundidade alemã, varios aspectos da história e da sociedade. $\mathrm{O}$ prineiro de Herder (Idee zum ersten patriotischen Institut fuer den Allgemeingeist Deutschlands, 1787 - Idéia sobre o primeiro Instituto patriótico sobre a universalidade alemã), o discurso inaugural da Associação Internacional dos Trabalhadores feito por Marx (1864), o ensaio de Max Weber, Os três tipos puros do Poder legítimo (Die drei reinen Typen der legitimen Herrschaft), as conferências de Freud de Introdução à Psicanalise (Vorlesungen zur Einfuehrung in die Psychoanalyse), os Deveres políticos da Juventude alemã (Politische Pflichten der deutschen Jugend, 1924), de Spengler, o discurso de Brecht no Primeiro Congresso Internacional de Escritores sobre a defesa da cultura (Rede auf dem Ersten Internationalen Schriftstellerkongress zur Verteidigung der Kultur), a conferência de Thomas Mann, A Alemanha e os Alemães (Deutschland und die Deutsche), feita no auditório Coolidge da Biblioteca do Congresso em Washington, aos 29 de maio de 1945, tentando mostrar as duas Alemanhas, os dois alemães, e condenando a brutalidade nazista. Finalmente o estudo de Theodor Adorno. "O conhecimento da sociologia do saber" (1953), encerra a antologia que, pelo seu criterioso carater seletivo dá uma idéia representativa da cultura alemã, de seus filósofos, poetas, historiadores, pensadores sociais e políticos. Mostra, tambem, que há uma tradição, um poder das idéias, e que a identidade nacional alemã contem $\mathrm{em}$ si mesma o conservadorismo e o militarismo prussiano e o liberalismo intelectual e político. As contradiçóes, as ambiguidades, os libertários e liberticidas, os conservadores e os revolucionários são próprios do espírito alemão, retratado nesta admiravel antologia.

O compilador lamenta não ter incluido Marcuse e Habermas, os dois neo-marxistas tão divergentes, e pessoalmente deploro que nem Mommsen, nem Meinecke, nem Ritter, os três grandes historiadores alemães estejam represen- 
tados. Esta antologia serve aos estudos de língua e literatura alemães, bem como aos de filosofia, história e sociologia.

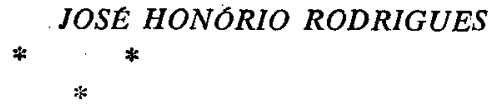

NICOULIN (Martin). - La Genèse de Nova Frigourgo: Emigration et Colonisation Suisse au Brésil - 1817-1827. Editions Universitaires, Fribourg, 1973. 364 págs.

Trata-se a presente obra do segundo volume da série Etudes et Recherches d'Histoire Contemporaine, coleção publicada por $\mathbf{R}$. Ruffieux, professor nas Universidades de Fribourg e Lausanne.

O livro (que originariamente foi a tese de doutoramento de seu autor) está dividido em três partes: na primeira, Les Suisses et l'Emigration sous la Restauration vai da página 21 à 150 . Encontramos aí um sumário sobre a emigração para a América no início do tempo da Restauração, os primeiros passos tomados pelo governo português (D. João VI) no sentido de trazer colonos suiços para o Rio de Janeiro e a importância da interferência do diplomata S. N. Gachet (conhecido então como le citoyen de Gruyères) nestas tramitações. Em seguida estuda o Autor todas as atividades oficiais no sentido de se estabelecer as bases jurídicas e as garantias para os imigrantes, o processo de escolha e seleção dos candidatos que aspiravam emigrar, assim como a participação dif̂erente de cada cantão suiço no contingente humano que partiu para o Novo Munđo. A preparação para a grande viagem e a travessia oceânica propriamente dita concluem a primeira seção desta obra.

A segunda parte traz o título Le Brésil et la Colonisation des Suisses (págs. 153-234). Aí o Autor entra em mais detalhes sobre as dificuldades da travessia do Velho para o Novo Mundo: tal realidade se torna mais clara e sensivel com a reprodução do depoimento de dois participantes desta aventura transcontinental (págs. 159-166). A chegada dos suiços no Rio de Janeiro, sua acolhida, o encontro dos imigrantes com a nova paisagem, a vida e o trabalho dos recem-chegados, suàs dificuldades, crises e șolução, eis alguns dos temas focalizados por M. Nicoulin.

Appareil Critique é o título da terceira parte (págs. 235-306). Aí vamos encontrar a transcrição de uma série de documentos referentes aos temas até então tratados: documentos diplomáticos, dados sociológicos (nome, sobrenome, idade e domicílio de cada imigrante subdividido por cantão), cartas de colonos enviadas a parentes que residiam na Suiça. Completa a obra um sugestivo e original capítulo que traz o título L'Aventure par l'Image, onde $\mathrm{M}$. Nicoulin reproduz, descreve e analisa quatro pinturas (duas aquarelas, uma aquatinta e uma litogravura) de pintores da época que retrataram aspectos da vida dos colonos de Nova Friburgo.

Para escrever seu livro o Autor realisou pesquisa em vinte e um Arquivos c Bibliotecas dos diferentes cantōes que contribuiram com emigrantes para a 